\title{
Control of Anthracnose by Chitosan through Stimulation of Defence-Related Enzymes in Eksotika II Papaya (Carica papaya L.) Fruit
}

\author{
Asgar Ali (corresponding author) \\ School of Biosciences, Faculty of Science, the University of Nottingham Malaysia Campus \\ Jalan Broga, Semenyih 43500, Selangor D.E., Malaysia \\ Tel: 60-3-8924-8219Ｅ-mail: Asgar.Ali@nottingham.edu.my \\ Mahmud Tengku Muda Mohamed \\ Department of Crop Science, Faculty of Agriculture, Universiti Putra Malaysia \\ Serdang, 43400 Selangor, D.E., Malaysia \\ Tel: 60-3-8946-7301Ｅ-mail: mahmood@agri.upm.edu.my
}

\begin{abstract}
Yasmeen Siddiqui
Department of Plant Protection, Faculty of Agriculture, Universiti Putra Malaysia

Serdang, 43400 Selangor, D.E., Malaysia
\end{abstract}

Tel: 60-1-7667-1219Ｅ-mail: yasmeenwarsi@yahoo.com

Received: January 31, 2012 Accepted: February 14, 2012

doi:10.5296/jbls.v3i1.1306 URL: http://dx.doi.org/10.5296/jbls.v3i1.1306

\begin{abstract}
The ability of chitosan to induce disease resistance in harvested Eksotika II papaya fruit was investigated in relation to the activities of several defence-related enzymes. Harvested papaya fruit were dipped in various concentrations of chitosan solutions $(0.5,1.0,1.5,2.0 \%)$ along with an untreated control and stored at $12 \pm 1{ }^{\circ} \mathrm{C}$ and $80-90 \%$ relative humidity for 15 days. Disease incidence and the activities of defence-related enzymes were monitored during storage. Compared with untreated fruit, chitosan treatments significantly reduced the severity of disease in fruit inoculated with Colletotrichum gloeosporioides. The activities of
\end{abstract}


defence-related enzymes peroxidase, chitinase, $\beta$-1,3-glucanase and total phenolic compounds were all significantly enhanced in 1.5 and $2.0 \%$ chitosan treated papaya fruit as compared to the control and $0.5 \%$ chitosan. Therefore, it could be suggested that postharvest decay in papaya can be minimized by chitosan application on a commercial scale.

Keywords: Edible coatings, Colletotrichum gloeosporioides, Carica papaya, Defence-related enzymes, Total phenols

\section{Introduction}

The fungal pathogens are the primary source of decay in fresh fruits and vegetables which ultimately cause considerable postharvest losses. Fresh fruits and vegetables are rich in moisture contents and due to their nutrient composition, they are susceptible to attack by pathogenic fungi. These problems make the fresh produce unfit for human consumption (Terry \& Joyce, 2004). To control these postharvest diseases, synthetic fungicides are commonly used (Pramila \& Dubey, 2004). However, the consistent use of these fungicides has developed some resistant strains of fungi and negative effects on human health have also limited the use of these fungicides (Corbo et al., 2009). The advancement in knowledge of increasing the potential of plants against these threats has become a promising technique to improve the crop protection (El Ghaouth et al., 2003).

Work on natural disease resistance has led to an outstanding perception of the key roles being played by some natural compounds in stimulating the defence response in plants. Elicitors of natural disease resistance may be natural, synthetic or physical (Benhamou, 1996). Natural disease resistance has been found against many postharvest diseases in harvested crops after using synthetic elicitors (Terry \& Joyce, 2004).

A promising option in the context of elicitor-induced resistance is the use of chitosan. In recent studies it has been found that chitosan-mediated induced resistance is a multifaceted process (El Ghaouth et al., 2000; Ben-Shalom et al., 2003; Romanazzi et al., 2003). The eliciting antifungal property of chitosan has been demonstrated in several postharvest produce by inducing hydrolases such as chitinase, $\beta, 1-3$ glucanase and chitosanase in cut strawberries, bell pepper, tomato and papaya (El Ghaouth et al., 1994). In chitosan-treated bell pepper and tomatoes, chitinase and $\beta$-1,3-glucanase were elevated for up to 14 days after treatment. The deliberate induction of lytic enzymes in harvested tissues by pre-storage treatment with chitosan can therefore give the tissues an advantage in restricting fungal colonization.

Some other enzymatic activities were also reported to elicit in palm roots when injected with chitosan (El-Hassni et al., 2004). Previous studies have shown that high peroxidase, glucanase and chitinase activities were related to resistance in several host-pathogen systems (Rout et al., 1999; Benhamou et al., 2001).

Induced resistance in vegetative tissues is well documented (Benhamou et al., 1996, 1998, 2001), but the induced resistance in harvested produce to control postharvest diseases is poorly studied (Bautista-Baños et al., 2006; Hewajulige et al., 2009a). In a recent study by our group it was found that chitosan has the potential to delay postharvest anthracnose (Ali et 
al., 2010) and extend shelf-life (Ali et al., 2011) of Eksotika II papaya for up to five weeks. Therefore, the objective of this study was to control anthracnose of papaya caused by Colletotrichum gloeosporioides using chitosan through stimulating defence-related enzymes.

\section{Materials and Methods}

\subsection{Materials}

Eksotika II papaya fruits of colour index-2 (green with traces of yellow) were obtained from a local exporter [Exotic Star (M) Sdn Bhd, Kajang, D.E. Selangor] on the same day of harvest. Papaya fruits were washed with sodium hypochlorite $(0.01 \%)$ for $3 \mathrm{~min}$, rinsed with distilled water and air-dried at the ambient temperature $\left(28 \pm 2{ }^{\circ} \mathrm{C}\right.$ ) (Ali et al., 2010). A locally prepared chitosan (shrimp shell, 95\% deacetylated) was obtained from the Chitin-Chitosan Research Centre of Universiti Kebangsaan Malaysia (UKM), Malaysia.

\subsection{Chitosan treatments}

Different concentrations of chitosan $(0.5,1.0,1.5$ and 2.0\%) were prepared according to the method described previously by Ali et al. (2010). Similarly the pure cultures of $C$. gloeosporioides were also prepared as explained by Ali et al. (2010). Air-dried papaya fruits were inoculated by dipping in a conidial suspension of $C$. gloeosporioides according to the method described by Ali et al. (2010) for $1 \mathrm{~min}$. The dipped fruit were air-dried again for $1 \mathrm{~h}$, followed by dipping in chitosan solutions $(0.5,1.0,1.5$ and $2.0 \%)$ or purified water (as control) for $30 \mathrm{~s}$ and re-dried for $2 \mathrm{~h}$ and then stored at $12 \pm 1{ }^{\circ} \mathrm{C}$ and $80-90 \%$ relative humidity for 15 days.

\subsection{Disease incidence}

Disease incidence data was recorded as explained previously by Ali et al. (2010). The data was expressed as the percentage of fruit showing anthracnose out of the total number of fruit in each treatment.

\subsection{Determination of total phenolic contents}

The phenolic contents in treated fruit were estimated using 1N Folin-Ciocalteau reagent as described by Zieslin and Ben-Zaken (1993). The concentration of total phenolic contents in the extract was calculated with chlorogenic acid as the standard.

\subsection{Extraction and assay of peroxidase}

The procedure for extraction of peroxidase was adapted from Mozzetti et al. (1995) while the activity of peroxidase enzyme was measured using guaiacol. The unit of peroxidase activity was calculated by the empirical formula of Kokkinakis and Brooks (1979).

\subsection{Extraction and assay of chitinase and $\beta$-1,3-glucanase}

The extraction of chitinase and $\beta$-1,3-glucanase enzymes were done according to the method of Tonon et al. (1998). Meanwhile the activity of chitinase was determined based on the rate of $\mathrm{N}$ - acetylglucosamine production using chitin as the substrate. The chitinase activity was expressed in nkat/mg fresh weight with $\mathrm{N}$-acetylglucosamine as the standard (Anfoka \& 
Buchenauer 1997). $\beta$-1,3-glucanase was assayed based on the rate of reducing sugar production using laminarin (Sigma) as substrate. Reducing sugar was determined by the Nelson Somogyi method (Robyt \& White 1987). $\beta$-1,3-glucanase activity was expressed as nkat/mg fresh weight with glucose as the standard (Anfoka \& Buchenauer 1997).

\subsection{Statistical analysis}

The experiment was arranged in a completely randomized design. The fruit were sampled for enzyme analysis at 0,3,6,9,12 and 15 day of storage. Data regarding disease incidence and enzymatic activity was subjected to analysis of variance (ANOVA) using SAS (Version 8.2). Least Significant Difference (LSD) test was used to separate the means at $P \leq 0.05$. Each treatment was replicated four times with 60 fruit per replicate and the experiment was repeated twice. The data was pooled together before analysis.

\section{Results and Discussion}

\subsection{Effect of chitosan treatments on disease incidence}

The control and $0.5 \%$ chitosan coated fruit were more susceptible to anthracnose. The control and $0.5 \%$ treated fruit started to develop small water-soaked patches within six days after inoculation. Disease incidence gradually increased over time. The water-soaked spots turned into circular sunken lesions with a translucent light brown margin. Disease incidence in control fruit was $24 \%$ after 15 days of storage. In fruit treated with 1.0, 1.5 and $2.0 \%$ chitosan, the disease symptoms were reduced in proportion to the increasing concentrations of chitosan used (Figure 1). The fruit treated with 1.5 and $2.0 \%$ chitosan showed no visible symptoms at all until the end of experiment, while the fruit treated with $1.0 \%$ chitosan showed $10 \%$ disease incidence after 15 days. The disease incidence in all chitosan treatments except $0.5 \%$ was significantly $(P \leq 0.05)$ lower from the control.

\subsection{Effect of chitosan treatments on total phenols}

The chitosan treatments except $0.5 \%$ produced a marked increase in total phenols. There was a significant $(P \leq 0.05)$ increase in total phenols in the fruit treated with $1.5 \%$ and $2.0 \%$ chitosan (Figure 2). Chitosan concentration at $1.5 \%$ maintained the total phenol level until the end of the experiment while in the $2.0 \%$ treatment, total phenols slightly declined. However, there was no significant difference between these two treatments after 15 days.

The higher phenolic activities in chitosan treated fruit at concentrations, 1.5 and $2.0 \%$ could be due to the compound acting as elicitors produced in host cells. A gradual decrease in total phenols was observed with increased disease incidence in the control fruit with the passage of time. The elicitation of disease resistant responses by chitosan in tomato, apples, citrus fruit and bell pepper has been observed in previous studies (El Ghaouth et al., 1994, 1997, 2003). It might be due to induction of various enzymes, the formation of physical barriers and plugging of intercellular spaces with antifungal phenolic-like compounds. Tan et al. (1982) found that in 20 varieties of papaya, the resistance conferred by phenolic compounds was through chlorogenic acid inhibiting the fungus. In a further study, they found that irradiated papaya had two fold the concentration of phenolic compounds than that in untreated fruit and 
also papaya fruit with higher contents of phenolic compounds were more resistant to fungal infection.

The involvement of total phenols in plant resistance is a widespread phenomenon including phytoalexins as well as constitutive substances (Gieger et al., 1993). The accumulation of phenols and activities of enzymes are known to be associated in biochemical defence mechanisms. The metabolism of phenolic compounds also involves oxidative enzymes such as peroxidase and polyphenol oxidase, which catalyze the oxidation of phenols to quinones (Gieger et al., 1993).

\subsection{Effect of chitosan treatments on peroxidase activity}

Peroxidase activity was significantly higher $(P \leq 0.05)$ in all treatments except $0.5 \%$ and control fruits during complete storage period. Peroxidase activity increased about four fold with 1.5 and $2.0 \%$ treatments and about two fold in $1.0 \%$ chitosan treatment compared to the control and $0.5 \%$ concentration (Figure 3). Peroxidase activity in fruits coated with $2.0 \%$ chitosan increased to a maximum at the $9^{\text {th }}$ day followed by a small decline though that decrease was not significant.

There has not been much work on the induction of peroxidase by chitosan. However, Vander Peter et al. (1998) found that peroxidase activity increased with the DA (degree of deacetylation) of chitosan in wheat leaves with no visible necrotic symptoms. This polycationic polymer may be interacted with the negatively charged phospholipids and as a result disturbd plant plasma membrane integrity and therefore affect the elicitor activity (Hoffland et al., 1996). In another study, Fajardo et al. (1998) observed that peroxidase activity was two to three fold that of the untreated control throughout the decay of oranges by Penicillium digitatum. Chitosan treated fruit showed the highest peroxidase activity than all the other treatments, like the application of aspire and margosan-O (chemical inducer), and reached a maximum at day 5 conferring lower disease incidence. A lower disease incidence may indicate the expression of induced resistance. The efficacy of elicitors in reducing incidence indicates that induced resistance can be effective, particularly in early infection of a disease (Hoffland et al., 1996).

Peroxidase has antifungal effects (Kristensen et al., 1999) and has been implicated in the defense responses to pathogens by various crops (Kazana et al., 1998; Anguelova et al., 1999). The increase in peroxidase activity has been shown to be associated with lignification, phenol oxidation and plant defence (Geiger et al., 1993; Hammerschmidt \& Yang-Cashman 1995). Therefore, the observation in this study of increased peroxidase activity in papaya fruit suggests that it is part of the mechanism of induced resistance by chitosan coating in the fruit.

\subsection{Effect of chitosan treatments on chitinase and $\beta$-1,3-glucanase activities}

A strong induction of chitinase activity in papaya fruit was observed in all the treatments with increasing concentration peaking at the $9^{\text {th }}$ day after inoculation (Figure 4). However, the increase by the $0.5 \%$ chitosan concentration was not significantly different from that of the control. Almost a similar trend was observed with glucanase activities. The activity peaked on day 9 in all the treatments (Figure 5). There was no significant difference between the 
levels in the control and $0.5 \%$ coated fruit. The maximum glucanase activity remained constant in 1.5 and $2.0 \%$ chitosan treatments until the end of the experiment. It is apparent from the data that effectiveness of the elicitor is dependent on the concentration of chitosan. The activity in the $1.0 \%$ treatment started to decline after the $9^{\text {th }}$ day with the onset of anthracnose spots.

The eliciting property of chitosan to control diseases in fruits and vegetables has been demonstrated in several studies (Eikemo et al., 2003; Hewajulige, 2009b). Chitosan treatment induced antifungal hydrolases such as chitinase, $\beta$-1,3-glucanase, and chitosanase in strawberry, raspberry, bell pepper and tomato (El Ghaouth et al., 1992a; Vander Peter et al., 1998, Benhamou et al., 2001). In chitosan-treated bell pepper and tomato, chitinase and $\beta$-1,3-glucanase remained elevated for up to 14 days after treatment. The deliberate induction of lytic enzymes in harvested produce in pre-storage treatment with chitosan can therefore give the produce a head start in restricting fungal colonization. This is indirectly supported by cytochemical results from chitosan-treated bell pepper in which the induction of chitinase and $\beta$-1,3-glucanase was followed by a substantial reduction in chitin labeling of the walls of the invading hyphae (El Ghaouth et al., 1994). The systemic nature of chitosan can be important in delaying the continuation of quiescent infections which normally become active only when the tissue resistance declines. If this is the case, such treatment can play an important role in controlling many postharvest diseases which normally arise after harvesting during storage due to the decrease in the potential of these tissues to produce antimicrobial compounds.

Fajardo et al. (1998) observed the induction of chitinase and $\beta, 1-3$ glucanase in flavedo of orange by the application of chitosan and challenged by the inoculation of P. digitatum. They found a relationship between the enzymes and disease incidence - the chitosan-treated fruit had lower disease incidence than the control which had lower enzyme activities. It could also be explained by a phenomenon that the best possible glucosamine polymer for both the functions must have a degree of polymerization of seven units or greater (Kendra et al., 1989).

The control of anthracnose observed so far with chitosan indicates that induction of defence responses in harvested papaya is possible and may offer a new technique for disease control. However, as the harvested produce mainly depends on its reserves to maintain cellular organization, thus, the potential of these fruits and vegetables to initiate defence response is likely to decline with ripening and exhaustion of their reserves. Therefore, any possible technique aimed to exploit the defence potential of papaya fruit should consider the physiological status and external factors affecting its physiology.

\section{Conclusion}

In conclusion, results of our study show that chitosan has the potential as a biocide for control of postharvest decay of papaya by $C$. gloeosporioides through inducing the accumulation of chitinase, $\beta$-1,3-glucanase, total phenols and peroxidase in the fruit. The reduction of anthracnose by chitosan application is likely the result of a multi-mode of action. The function of chitosan appears to be a direct antifungal effect on fungi, consequently increasing their susceptibility to the host chitinase and $\beta-1,3$-glucanase as well as lytic enzymes. 


\section{References}

Ali A., Mahmud T. M. M., Sijam K., Siddiqui Y. (2010). Potential of chitosan coating in delaying the postharvest anthracnose (Colletotrichum gloeosporioides Penz.) of Eksotika II papaya. International Journal of Food Science and Technology, 45:2134-2140. http://dx.doi.org/10.1111/j.1365-2621.2010.02389.x

Ali A., Mahmud T. M. M., Sijam K., Siddiqui Y. (2011). Effect of chitosan coatings on the physicochemical characteristics of Eksotika II papaya (Carica papaya L.) fruit during cold storage. Food Chemistry, 124:620-626. http://dx.doi.org/10.1016/j.foodchem.2010.06.085

Anfoka G., Buchenauer H. (1997). Systemic acquired resistance in tomato against Phytophthora infestans by pre-inoculation with tobacco necrosis virus. Physiological and Molecular Plant Pathology, 50: 85-101. http://dx.doi.org/10.1006/pmpp.1996.0072

Anguelova V. S., Van Der Westhuizen A., Pretorius Z. A. (1999). Intercellular proteins and $\beta$-1,3-glucanase activity associated with leaf rust resistance in wheat. Plant Physiology, 106: 393-401. http://dx.doi.org/10.1034/j.1399-3054.1999.106406.x

Bautista-Baños S., Hernández-Lauzardo A. N., Velázquez-del Valle M. G., Hernández-López M., Ait Barkab E., Bosquez-Molina E., Wilson C. L. (2006). Chitosan as a potential natural compound to control pre and postharvest diseases of horticultural commodities. Crop Protection, 25:108-118. http://dx.doi.org/10.1016/j.cropro.2005.03.010

Ben-Shalom N., Ardi R., Pinto R., Aki C., Fallik E. (2003). Controlling gray mould caused by Botrytis cinerea in cucumber plants by means of chitosan. Crop Protection, 22: 275-283. http://dx.doi.org/10.1016/S0261-2194(02)00149-7

Benhamou N. (1996). Elicitor-induced plant defence pathways. Trends in Plant Science, 1:233-240. http://dx.doi.org/10.1016/S1360-1385(96)86901-0

Benhamou N., Kloepper J.W., Tuzun S. (1998). Induction of resistance against Fusarium wilt of tomato by combination of chitosan with and endophytic bacterial strain: ultra structure and cytochemistry of the host response. Planta, 204:153-168. http://dx.doi.org/10.1007/s004250050242

Benhamou N., Langer R., Rey P., Tirilly Y. (2001). Oligandrin, the elicitin-like protein produced by the mycoparasite Pythium oligandrum, induces systemic resistance to Fusarium crown and root rot in tomato plants. Plant Physiology and Biochemistry, 39:681-696. http://dx.doi.org/10.1016/S0981-9428(01)01283-9

Corbo M. R., Bevilacqua A., Campaniello D., D’Amato D., Speranza B., Sinigaglia M. (2009). Prolonging microbial shelf life of foods through the use of natural compounds and non-thermal approaches - a review. International Journal of Food Science and Technology, 44:223-241. http://dx.doi.org/10.1111/j.1365-2621.2008.01883.x

Eikemo H., Stensvand A., Tronsmo A. M. (2003). Induced resistance as a possible means to control diseases of strawberry caused by Phytophthora spp. Plant Disease, 87:345-350. http://dx.doi.org/10.1094/PDIS.2003.87.4.345 
El Ghaouth A., Arul J., Grenier J., Asselin A. (1992a). Antifungal activity of chitosan on two postharvest pathogens of strawberry fruits. Phytopathology, 82:398-402. http://dx.doi.org/ 10.1094/PHYTO-82-398

El Ghaouth A., Arul J., Wilson C., Asselin A., Benhamou N. (1994). Ultrastructural and cytochemical aspects of the effect of chitosan on decay of bell pepper fruit. Physiological and Molecular Plant Pathology, 44:417-432. http://dx.doi.org/10.1016/S0885-5765(05)80098-0

El Ghaouth A., Arul J., Wilson C., Benhamou N. (1997). Biochemical and cytochemical aspects of the interactions of chitosan and Botrytis cinerea in bell pepper fruit. Postharvest Biology and Technology, 12:183-194. http://dx.doi.org/10.1016/S0925-5214(97)00056-2

El Ghaouth A., Smilanick J. L., Wilson C. L. (2000). Enhancement of the performance of Candida saitoana by the addition of glycolchitosan for the control of postharvest decay of apple and citrus fruit. Postharvest Biology and Technology, 19:103-110. http://dx.doi.org/10.1016/S0925-5214(00)00076-4

El Ghaouth A., Wilson C. L., Wisniewski M. (2003). Control of postharvest decay of apple fruit with Candida saitoana and induction of defence responses. Phytopathology, 93:344-348. http://dx.doi.org/10.1094/PHYTO.2003.93.3.344

El Hassni M., El Hadrami A., Daayf F., Ait Barka E., El Hadrami I. (2004). Chitosan, antifungal product against Fusarium oxysporum f. sp. albedinis and elicitor of defence reactions in date palm roots. Phytopathologia Meditteranea, 43:195-204.

Fajardo J. E., McCollum T. G., McDonald R. E., Mayer T. (1998). Differential induction of proteins in orange flavedo by biologically based elicitors and challenged by Penicillium digitatum Sacc. Biological Control, 13:143-151. http://dx.doi.org/10.1006/bcon.1998.0661

Geiger J. P., Nicole M., Topan A., Roby D., Benhamou N., Rio B., Nandris D. (1993). Lignification: A defence reaction of trees to rotting fungi. In: Fritig, B. and Legrand, M. (eds), Mechanism of Plant Defence Responses. The Netherlands: Kluwer Academic Publishers, p.355.

Hammerschmidt R., Yang-Cashman P. (1995). Induced resistance in cucurbits. In: Hammerschmidt R. and Kuc J., (eds), Induced Resistance to Disease in Plants. Dordrecht: The Netherlands: Kluwer Academic Publishers, pp.63-85.

Hewajulige I. G. N., Sultanbawa Y., Wijeratnam R. S. W., Wijesundara R. L. C. (2009a). Effect of irradiated chitosan treatment on storage life of fruits of two commercially grown papaya (Carica papaya L.) varieties. Journal of the National Science Foundation of Sri Lanka, 37: 61-66. http://dx.doi.org/10.4038/jnsfsr.v37i1.458

Hewajulige I. G. N., Sultanbawa Y., Wijeratnam R. S. W., Wijesundara R. L. C. (2009b). Mode of action of chitosan coating on anthracnose disease control in papaya. Phytoparasitica, 37:437-444. http://dx.doi.org/10.1007/s12600-009-0052-5 
Hoffland E., Hakulinen J., van Pelt J. A. (1996). Comparisons of systemic resistance induced by avirulent and nonpathogenic Pseudomonas species. Biological Control, 86:757-762. http://dx.doi.org/10.1094/Phyto-86-757

Kazana K., Goulter K. C., Way H. M., Manners J. M. (1998). Expression of pathogenesis-related peroxidase of Stylosanthes humilis in transgenic tobacco and canola and its effect on disease development. Plant Science, 136:207-217. http://dx.doi.org/10.1016/S0168-9452(98)00108-3

Kendra D. F., Christian D., Hadwiger L. A. (1989). Chitosan oligomers from Fusarium solani/ pea interactions, chitinase / $\beta$-glucanase digestion of sporelings and from fungal wall chitin actively inhibit fungal growth and enhance disease resistance. Physiological and Molecular Plant Pathology, 35:215-230. http://dx.doi.org/10.1016/0885-5765(89)90052-0

Kokkinakis D. M., Brooks J. L. (1979). Tomato peroxidases: Purification, characterization and catalytic properties. Plant Physiology, 63:93-99.

Kristensen B. K., Bloch H., Rasmussen S. K. (1999). Barley coleoptiles peroxidases: Purification, molecular cloning and induction by pathogen. Plant Physiology, 120:501-512. http://dx.doi.org/10.1104/pp.120.2.501

Mozzetti C., Farraris I., Tamietti G., Matta A. (1995). Variations in enzyme activities in leave and cell suspension as markers of incompatibility in different Phytophthora-pepper interactions. Physiological and Molecular Plant Pathology, 46:91-107. http://dx.doi.org/10.1006/pmpp.1995.1008

Pramila T., Dubey N. K. (2004). Exploitation of natural products as an alternative strategy to control postharvest fungal rotting of fruit and vegetables. Postharvest Biology and Technology, 32:235-245. http://dx.doi.org/10.1016/j.postharvbio.2003.11.005

Robyt J. F., White B. J. (1987). Biochemical techniques theory and practice. IL: Waveland Press Inc. USA. pp.217-219.

Romanazzi G., Nigro F., Ippolito A. (2003). Short hypobaric treatments potentiate the effect of chitosan in reduction storage decay of sweet cherries. Postharvest Biology and Technology, 29:73-80. http://dx.doi.org/10.1016/S0925-5214(02)00239-9

Rout G. R., Samantaray S., Das P. (1999). Root induction in microshoots of Simarouba glauca L. in vitro: Peroxidase as a marker for rooting. Silvae Genetica, 48:14-17.

Tan S. C., Teo S. W., Adam A. G. (1982). Factors affecting fungal resistance in papaya fruits. Sains Malaysiana, 11:21-31.

Terry L. A., Joyce D. C. (2004). Elicitors of induced disease resistance in postharvest horticultural crops: a brief review. Postharvest Biology and Technology, 32:1-13. http://dx.doi.org/10.1016/j.postharvbio.2003.09.016 
Tonon C., Andreu A., Aued M. E., Van Damme M., Huarte M., Daleo G. R. (1998). Defence reaction in two potato cultivars following infection with two races of Phytophthora infestans. Potato Research, 41:319-325. http://dx.doi.org/10.1007/BF02358964

Vander Peter K. M., Varum A., Domard N. E. E. (1998). Comparison of ability of partially $\mathrm{N}$-Acetylated chitosan and chito-oligosaccharides to elicit resistance reactions in wheat leaves. Plant Physiology, 118:1353-1359. http://dx.doi.org/10.1104/pp.118.4.1353

Zieslin N., Ben-Zaken R. (1993). Peroxidase activity and presence of phenolic substances in peduncles of rose flowers. Plant Physiology and Biochemistry, 31:333-339.

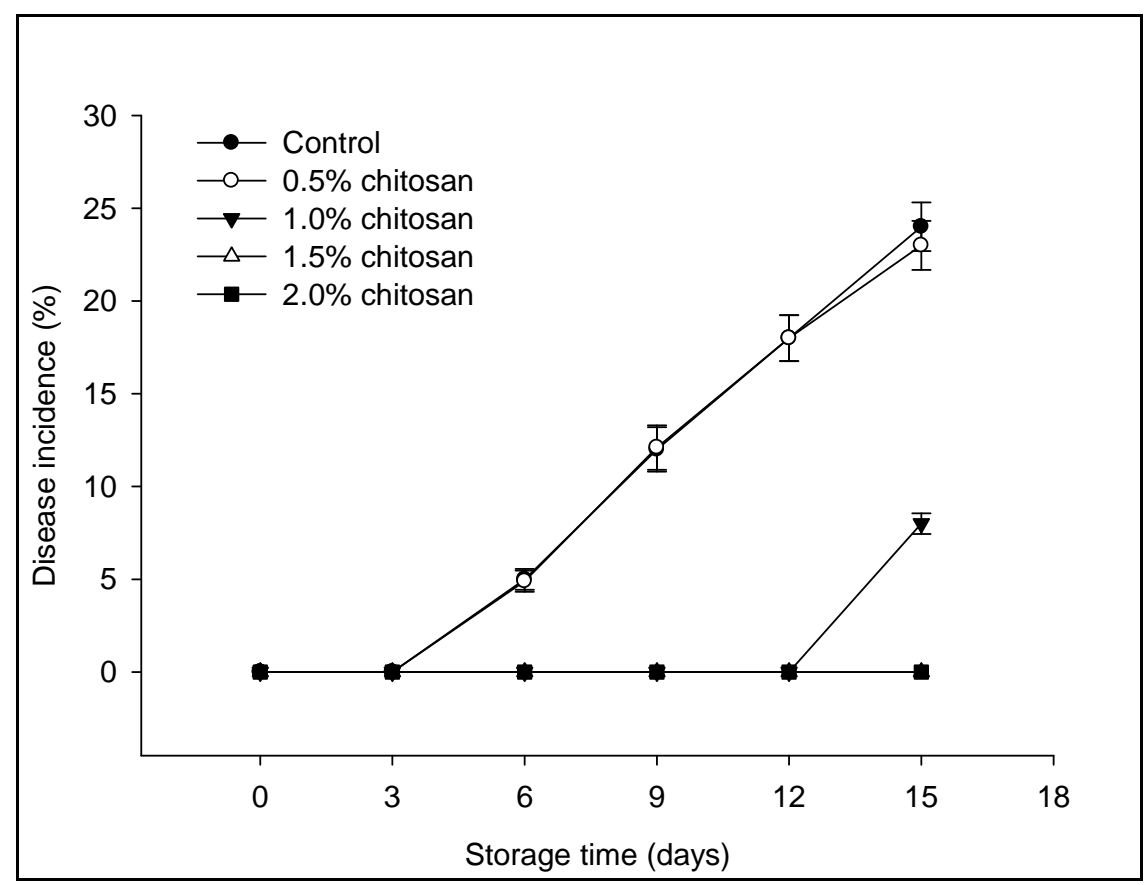

Figure 1. Effect of different concentrations of chitosan on anthracnose incidence (\%) in papaya fruit. Vertical bars represent \pm S.E. of the mean (four replicates). 


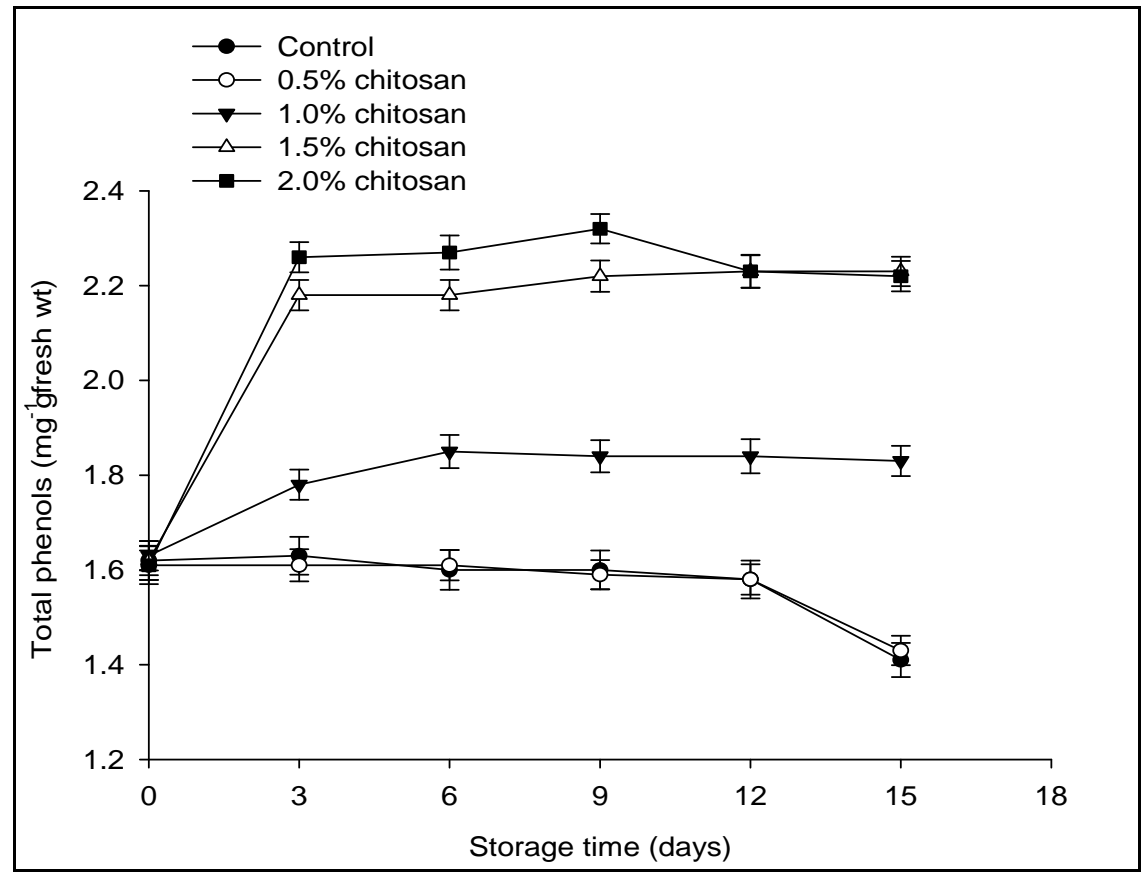

Figure 2. Total phenols in papaya fruit treated with different concentrations of chitosan and inoculated with $C$. gloeosporioides. Vertical bars represent \pm S.E. of the mean (four replicates).

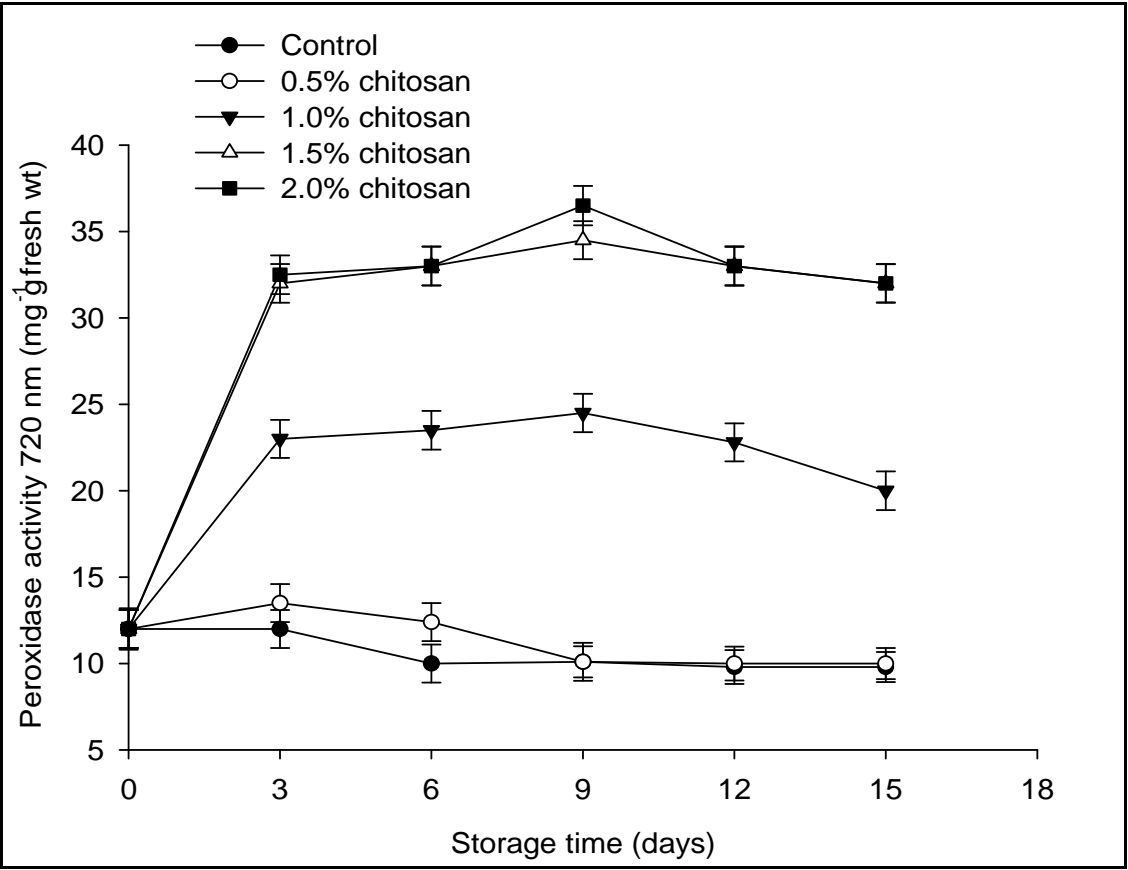

Figure 3. Peroxidase (POD) activity in papaya fruit treated with different concentrations of chitosan and inoculated with $C$. gloeosporioides. Vertical bars represent \pm S.E. of the mean (four replicates). 


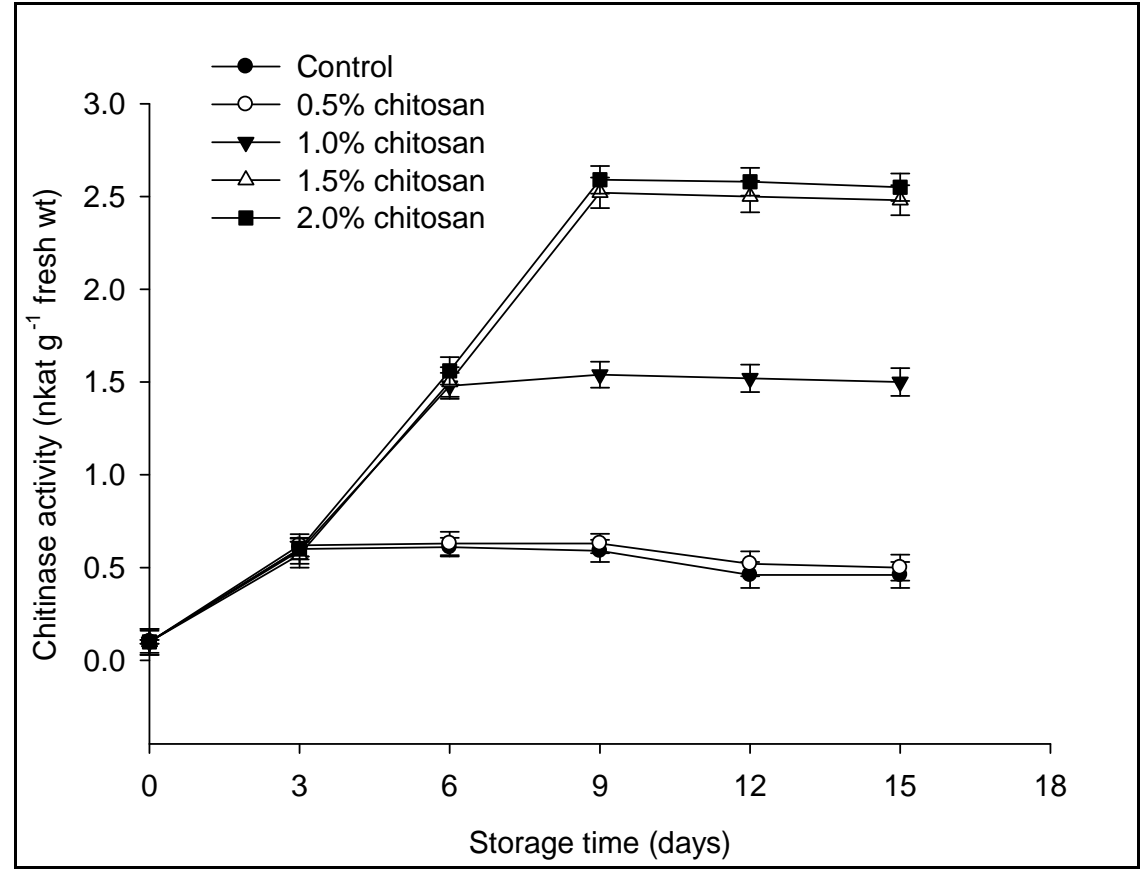

Figure 4. Chitinase activity in papaya fruit treated with different concentrations of chitosan and inoculated with $C$. gloeosporioides. Vertical bars represent \pm S.E. of the mean (four replicates).

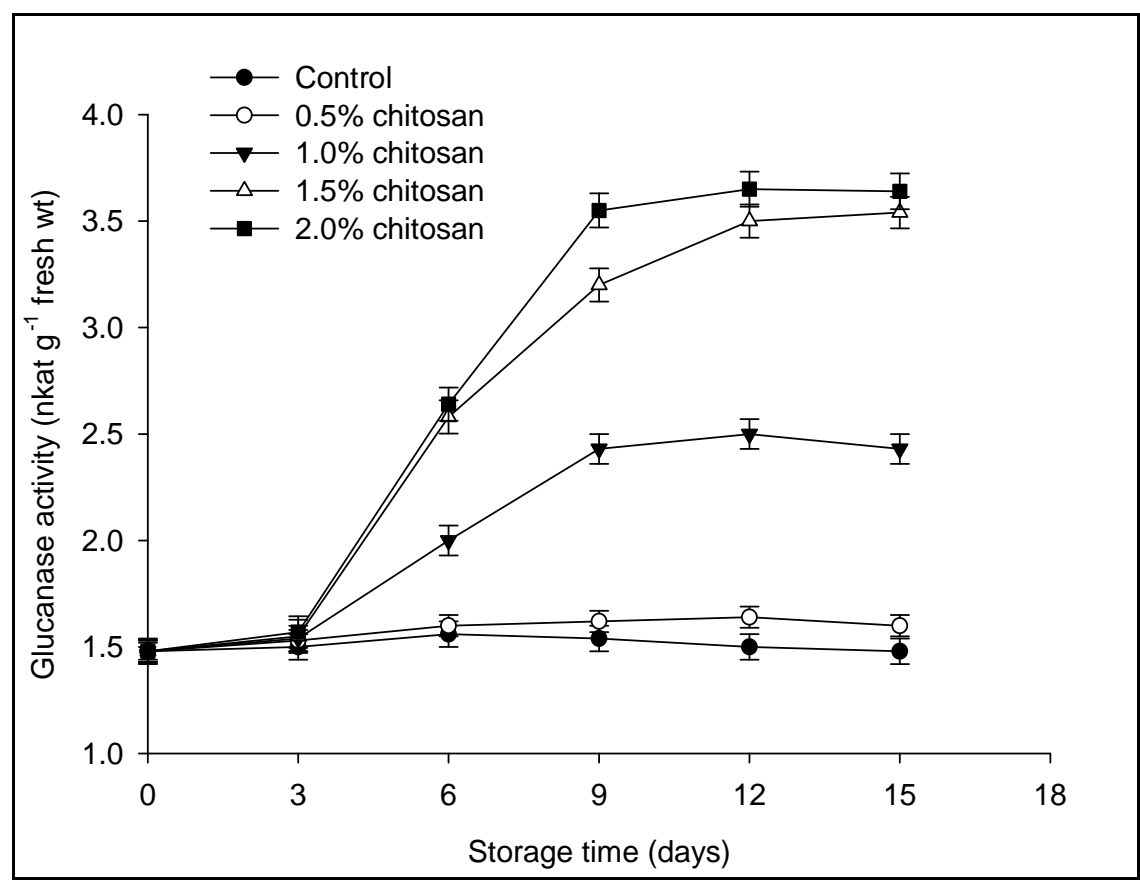

Figure 5. Glucanase activity in papaya fruit treated with different concentrations of chitosan and inoculated with C. gloeosporioides. The vertical bars represent the standard error of means for four replicates 


\section{Copyright Disclaimer}

Copyright reserved by the author(s).

This article is an open-access article distributed under the terms and conditions of the Creative Commons Attribution license (http://creativecommons.org/licenses/by/3.0/). 